\title{
Climate Ethics and Policy in Africa ${ }^{1}$
}

\author{
Workineh Kelbessa
}

Department of Philosophy

Addis Ababa University, Ethiopia

workinehkelbessa@yahoo.com

DOI: http://dx.doi.org/10.4314/tp.v7i2.4

Thought and Practice: A Journal of the Philosophical Association of Kenya (PAK)

New Series, Vol.7 No.2, December 2015, pp.41-84

thoughtandpractice@gmail.com

http://ajol.info/index.php/tp

ISSN: 2076-7714

\footnotetext{
${ }^{1}$ I would like to thank Niels Weidtmann, Rainer Ebert, Thummapudi Bharathi, the two anonymous reviewers and the editor-in-chief of this journal for their constructive suggestions and comments on the earlier draft. I would also like to specifically thank the Alexander von Humboldt Foundation for supporting my research at the Forum Scientiarum of the University of Tubingen, Germany.
} 


\begin{abstract}
In this article, I use case studies from some African countries to determine whether or not African climate management policies have been guided by ethical principles. I argue that although climate change is fundamentally an ethical issue, African policymakers have not paid sufficient attention to ethical principles in this regard. I argue that the major ethical principles embodied in different African traditions can assist African and non-African countries to address the challenges occasioned by climate change. Finally, I suggest that technological societies whose current emissions most exceed their fair share of emissions ought to give attention to justice, and play their respective roles in averting the most extreme effects of climate change.
\end{abstract}

\title{
Keywords
}

African ethics, climate ethics, climate change, climate policy, inter-generational justice

\section{Acronyms}

AR2

BNRCC

COP

CRGE

CSOs

EEPA

FDRE

GHG

IPCC

NAMAs

NAPA

NASA
Second Assessment Report

Building Nigeria's Response to Climate Change

Conference of the Parties

Climate-Resilient Green Economy

Civil Society Organisations

Ethiopian Environmental Protection Authority

Federal Democratic Republic of Ethiopia

Greenhouse Gas

Intergovernmental Panel on Climate Change

Nationally Appropriate Mitigation Actions

National Adaptation Programme of Action

National Aeronautics and Space Administration (An independent agency of the United States government responsible for aviation and space flight) 


$\begin{array}{ll}\text { NASPA-CCN } & \text { National Adaptation Strategy and Plan of Action on Climate } \\ \text { Change for Nigeria } \\ \text { NBPE } & \text { National Biogas Program for Ethiopia } \\ \text { NCCAP } & \text { National Climate Change Action Plan } \\ \text { NCCC } & \text { National Climate Change Coordinating Committee } \\ \text { NCCR } & \text { National Climate Change Response } \\ \text { NCCRS } & \text { National Climate Change Response Strategies } \\ \text { NDP } & \text { National Development Plan } \\ \text { NEMA } & \text { National Environmental Management Act } \\ \text { NPCC-RS } & \text { National Policy on Climate Change and Response Strategy } \\ \text { PPP } & \text { The Polluter Pays Principle } \\ \text { REDD } & \text { Reducing Emissions from Deforestation and Forest } \\ & \text { Degradation } \\ \text { UNEP } & \text { United Nations Environmental Programme } \\ \text { UNFCCC } & \text { United Nations Framework Convention on Climate Change }\end{array}$

\section{Introduction}

Climate change is one of the most urgent problems that humanity is facing today. However, not all scientists and philosophers agree on its nature and consequences. There are arguments both for and against the reality of climate change. Nevertheless, since the nineteenth century, various scientists have been alerting humankind about the dangers of global warming. To mention but a few, Joseph Fourier, a French mathematician and physicist, explained the heating of the earth in his article in 1827. On his part, John Tyndal (1861), a British scientist, carried out an experiment in 1859 to show the greenhouse effect. Furthermore, in 1896, the Swedish Nobel Prizewinning physicist, Svante Arrhenius, was one of the first scholars to indicate the possibility of anthropogenic (human-caused) climate change. Besides, National Aeronautics and Space Administration (NASA) scientist James Hansen, in his 1988 paper, provided "the first rigorous, data-based, scientifically grounded explanation of anthropogenic climate change" (Rentmeester 2014, 6).

Although various scientists, historians and philosophers discussed the causes and consequences of environmental degradation in the second half of the $20^{\text {th }}$ century, 
climate change was not the major point of discussion until recently. Furthermore, it was only in the 1980s that scientists and scientific organisations began to induce governments to take climate problems into account. In 1988, the United Nations Environmental Programme (UNEP) and the World Meteorological Organisation established an international body, the Intergovernmental Panel on Climate Change (IPCC), to conduct assessments of scientific knowledge of climate change. Since its establishment in 1988, the IPCC has produced five major assessment reports in 1990, 1995, 2001, 2007 and 2013/2014.

Successive findings of the IPCC and of other writers show that anthropogenic climate change is a reality. Although the earth's surface is warming up due to natural causes, climate change is largely human-made (anthropogenic). Industrial production practices, transport, energy consumption, mass consumerism, changes in land-use patterns (principally, deforestation) and the global livestock industry are the main anthropogenic sources of greenhouse gases. Various studies have shown that the effects of climate change are being felt in different parts of the world (Jamieson 2003; Gardiner 2004; Rolston 2012; Attfield 2010 and 2014). After examining 928 articles on climate change published in peer-reviewed journals between 1993 and 2003, Naomi Oreskes concludes that these articles confirmed the main conclusions of the IPCC in 2001 (Oreskes 2004, cited in Arnold 2011, 4). Moreover, most major scientific organisations including the academies of science for the G8 +5 (the National Science Academies of Brazil, Canada, China, France, Germany, India, Italy, Japan, Mexico, Russia, South Africa, the UK and the USA) have endorsed the findings of the IPCC about global climate change in a joint statement (see Arnold 2011, 6). Similarly, leading global companies including Alcan, Alcoa, BP, BHP Billiton, Dow Chemical, Iberdrola, Novo Nordisk, Scottish Power, Royal Dutch Shell, STMicroelectronics and Weyerhauser have recognized the reality of anthropogenic climate change (Business Week 2005, cited in Arnold 2011, 6).

The IPCC's Fourth and Fifth Assessment Reports have identified a number of areas where scientific evidence and observations enabled humanity to understand the negative impacts of anthropogenic global warming. Indeed, in its latest report, it confirmed that human activities have contributed to climate change: "It is extremely likely that human influence has been the dominant cause of the observed warming 
since the mid-20 ${ }^{\text {th }}$ century" (IPCC 2013, 17; emphasis in original). According to the IPCC, "[t]he atmospheric concentrations of the greenhouse gases carbon dioxide $\left(\mathrm{CO}_{2}\right)$, methane $\left(\mathrm{CH}_{4}\right)$, and nitrous oxide $\left(\mathrm{N}_{2} \mathrm{O}\right)$ have all increased since 1750 due to human activity" (IPCC 2013, 11). The IPCC further states that mitigation policies have not prevented the growth of Greenhouse Gas (GHG) emissions: "Total anthropogenic GHG emissions were the highest in human history from 2000 to 2010 and reached $49( \pm 4.5) \mathrm{GtCO} 2 \mathrm{eq} / \mathrm{yr}$ in 2010” (IPCC 2014b, 6).

Although climate change affects all countries, the world's poorest countries face the most severe impact. It is the wealthy who are using most of the energy that leads to the emissions that cause climate change, while it is the poor who will bear most of the costs. In particular, climate change is a reality in Africa. According to the regional study of the IPCC, "[e]vidence of warming over land regions across Africa, consistent with anthropogenic climate change, has increased (high confidence). Decadal analyses of temperatures strongly point to an increased warming trend across the continent over the last 50 to 100 years" (Niang et. al. 2014, 1202; emphasis in original). Africa contributes less than $4 \%$ to global emissions of GHGs, $75 \%$ of which are from land use changes (deforestation and land degradation) - an insignificant contribution. Yet Africa has been suffering from rising temperatures and evaporation, widespread water stress, increased frequency and severity of droughts and floods, crop loss, rising sea levels, ocean acidification, decline in biodiversity, high levels of disease, and conflicts over access to land and water (Kelbessa 2009, 261; IPCC 2007, cited in Kelbessa 2009, 254 \& 255). These are serious ethical issues that need to be addressed.

Several African countries have already formulated national climate policies to address the challenges of climate change. Using case studies from some African countries, this article seeks to determine whether or not African climate policies have been guided by ethical principles. In the next section, I will briefly discuss the ethical dimensions of climate change and arguments for inaction. That will be followed by a section in which I will briefly explore the climate policies of Ethiopia, Kenya, Uganda, South Africa and Nigeria. Some of the reasons for reviewing the climate policies of these countries are the availability of relevant works on the environmental policies of some of them, and the contributions of some of them to GHG emissions. I 
chose South Africa and Nigeria partly because they are the largest emitters of GHGs in Africa. Thereafter, there is a section which examines the role of climate ethics and African ethics in addressing climate change. There I will argue that African ethics can contribute to measures aimed at addressing climate change.

\section{Mapping the Ethical Dimensions of Climate Change and Arguments for Inaction}

The debate on climate change has thus far been dominated by scientific, technical and economic analysis. Policy makers have appealed to scientists and economists to determine facts and envisage harms and benefits of proposed policies respectively. However, scientific and economic arguments conceal moral issues. The ethical dimensions of climate change have been ignored for too long, although Article 2 of the United Nations Framework Convention on Climate Change (UNFCCC) recognises the complimentary roles of ethics and economics. What nations should do about climate change is an ethical question. Previous Intergovernmental Panel on Climate Change (IPCC) assessment reports did not give sufficient attention to ethics, although the Second Assessment Report (AR2) covered aspects of both economics and ethics (Kolstad et. al. 2014, 214). The most recent report of the IPCC has for the first time paid attention to the ethical and justice aspects of climate change (see Fleurbaey et. al. 2014 and Kolstad et. al. 2014).

Initially, many philosophers thought that climate change was the concern of people in other disciplines. However, this has been challenged by some philosophers who conceive climate change as fundamentally an ethical issue (see Coward and Hurka 1993; Jamieson 2001 and 2003; Gardiner 2004; Garvey 2008; Irwin 2010; Arnold 2011; Brown 2011; Bell 2013; Attfield 2010 and 2014). I will discuss this issue further in the penultimate section.

Climate change raises issues of corrective justice and inter-generational justice, as emissions of greenhouse gases negatively affect not only the current generation of humankind but also future ones, non-human species and the natural environment because they can stay in the atmosphere for hundreds and even thousands of years (Martin-Schramm 2010, xvi; Gardiner 2011, 8 and 34; Light 2011). The effects of the 
current anthropogenic global warming are not immediately visible. Current GHG emissions will stay in the atmosphere for a long time before causing any harm. This reflects the inter-generational dimension of climate change, as our current emissions will have negative impacts on future generations. Thus we need to understand the various causes of carbon dioxide in the world and its persistence in the atmosphere for a long time.

Climate change requires an interdisciplinary approach, as one field of knowledge cannot cover all of its dimensions. Consequently, it would be misguided to focus only on its scientific, technical and economic aspects while ignoring its other dimensions.

On the other hand, some climate sceptics have questioned the reality of anthropogenic climate change, and rejected the IPCC consensus on it. They believe that there has been no sound scientific evidence that confirms that human beings are increasing the amount of greenhouse gases in the atmosphere (Singer 1997; Lomborg 2001; Irwin and Williams 2010). Consequently, they have discouraged countries from taking measures to address the problem of climate change. They offer the following reasons for doing little or nothing at all: uncertainty, costs, technological rescue, and waiting for others to act (see Garvey 2008; Arnold 2011; Fossil Free MIT 2014). In this article, I will not discuss these reasons in any depth, but will only briefly comment on some of them.

Nevertheless, it is true that there are uncertainties about the future manifestation of climate change, what the carbon sinks of the world can absorb, the regional patterns of climate change and impacts, changes in mean rainfall, rainfall variability and associated hydrological processes (Garvey 2008, 93-94; Williams and Kniveton 2011, 2-3), and the magnitude and timing of future warming. Accordingly, it will be difficult to have full certainty over future rainfall changes and water availability. Yet the fossil fuel industry has funded some scientists and groups who have participated in the anti-climate-change-action lobbying and anti-climate-science disinformation campaigns. Consequently, some scientists have deliberately tried to discredit the science of climate change (see Oreskes and Conway 2010). Christopher C. Horner (2007) is one of these scientists. Among others, the Global Climate Coalition has contributed to climate science disinformation campaigns, engaging in discrediting the 
IPCC's senior scientists (Layzer 2007). Accordingly, climate sceptics have tried to delay the formulation of climate change policies in the name of science. This is unethical and counterproductive.

Besides, various developed countries that dominate greenhouse gas production are reluctant to take measures to ameliorate global climate change because of their national interests (Garvey 2008). They think that addressing climate change would cost too much, and that climate change legislation would have negative impacts on job creation, GDP, and the development of some businesses including the coal and petroleum industries. As a result, they allow economic concerns to swamp moral concerns. However, this is not the right thing to do, as they fail to fulfil their obligations to others to reduce their GHG emissions. They also fail to take into account the potential damage from climate change, and future benefits from climate change mitigation.

Others believe that future technology can help solve the problem that climate change causes, so that there is no urgency to take action. Stephen Pacala and Robert Socolow even claim that the current technology can enable humanity to stabilise carbon emissions at present levels within 50 years (Pacala and Socolow 2004, cited in Garvey 2008, 103). Similarly, many writers propose technological fixes such as geoengineering (the deliberate large-scale manipulation of the climate system). It is the third attempt to respond to climate change, besides mitigation and adaptation. Various writers have proposed different types of solar radiation management (SRM) and carbon dioxide removal (CDR). Geoengineering projects include sulphur injections into the atmosphere, reflecting solar radiation with space mirrors, removing carbon from the atmosphere, iron fertilization of oceans, and so on (Caney 2011, 81-83; Attfield 2014, 212-216).

However, some thinkers have serious doubts about many of the geo-engineering projects (Caney 2011). They suspect that an increase in methane hydrate may result from iron or phosphate fertilization of the oceans, thereby aggravating climate change (Keith 2000, 270). They also point out that the availability of sulphur particles in the atmosphere can further deplete the ozone layer (Keith 2000, 271). 
Nevertheless, it does not follow that all kinds of geo-engineering projects are futile: some of them may address the above mentioned challenges. There is no doubt that humanity needs enormous technological innovation to deal with climate change. Alternative and yet efficient sources of energy are desperately needed. The point is that we should study the ethical implications of new technologies, including their potential long-term adverse impact on social justice, and make sure that their risks are justified by their potential benefits before applying them.

Waiting for others to act is another reason for inaction. Although UN member states agreed that developed countries should shoulder most of the burden (at least initially) for addressing climate change, the U.S. government refused to sign the Kyoto protocol, pointing out that China and India were not forced to reduce their emissions, so that for the U.S. government, it is a "flawed treaty" (Garvey 2008, 108).

We should note that the magnitude of the developed and developing worlds' emissions is not the same. The US stands first in the world in per capita and cumulative emissions, although China is the world's largest emitter in absolute terms, and has wealthy persons who have high per capita emissions (Olivier et. al. 2015, 5). In other words, the US is the greatest source of carbon emissions to date, so she ought to bear the highest degree of responsibility to curb climate change. Temporarily reserving free emissions for developing countries ought not to be judged as unjust, as most of them have not yet satisfied their basic needs. What others do or do not do ought not to prevent countries from taking morally desirable action. What is important is that all nations ought to reduce their GHG emissions.

\section{Climate Policy in Africa}

Although all regions of Africa have already initiated governance systems for adaptation to climate change, regional policies and strategies for adaptation, as well as trans-boundary adaptation are still in their early stages (Niang et. al. 2014). Some African countries have already developed National Adaptation Programmes of Action (NAPAs) in the case of the Least Developed Countries, or National Climate Change Response Strategies (NCCRS) (Niang et. al. 2014, 1227). The following case studies show how some African countries have responded to climate change and its impacts. 


\section{Climate Policy in Ethiopia}

The current Ethiopian government developed the first comprehensive national conservation strategy and a new environmental policy in 1997 so as to promote sustainable social and economic development. Similarly, all the Regional States and City Administrations in the country have established their respective Environmental Protection and Conservation Strategies (Kelbessa 2014, 34). In addition, the country signed and ratified international environmental agreements, including the United Nations Framework Convention on Climate Change in 1994, the Convention on Biological Diversity in 1994, the United Nations Convention to Combat Desertification in 1994, the Cartagena Protocol on Bio-safety to the Convention on Biological Diversity in 2000, and the Kyoto Protocol in 2005. Furthermore, Ethiopia prepared its Programme of Adaptation to Climate Change (EPACC), and Nationally Appropriate Mitigation Actions (NAMAs) to respond to climate change. The EPACC is the revised version of the country's National Adaptation Programme of Action (NAPA), which was formulated in 2007. Ethiopian adaptation to climate change includes national, regional and local community levels. Following the Copenhagen Accord in 2009, the country formulated and submitted its Nationally Appropriate Mitigation Actions to the Executive Secretary of the UNFCCC in 2010.

Ethiopia aspires to build a climate-resilient green economy (FDRE 2011). The Government of the Federal Democratic Republic of Ethiopia (GFDRE) conceives green growth as a necessity, and so endeavours to promote renewable energy and control agro-ecological degradation. It has identified agriculture, health, water, energy, buildings and transport sectors as most vulnerable to the effects of climate change. It thus initiated "the Climate-Resilient Green Economy (CRGE) to protect the country from the adverse effects of climate change and to build a green economy that will help realise its ambition of reaching middle-income status before 2025" (FDRE 2011, III). Accordingly, the government aims to achieve middle income country status and a climate resilient economy in a carbon neutral way by the year 2025 .

It is estimated that if Ethiopia continues to promote the conventional development path, its GHG emissions will be about $400 \mathrm{Mt} \mathrm{CO} 2 \mathrm{e}$ (carbon dioxide equivalent) in 
2030, which means 250 additional Megatons of carbon dioxide equivalent (Mt CO2e). Currently, the country's GHG emissions are estimated to be $150 \mathrm{Mt}$ CO2e. Consequently, a climate resilient green development is conceived to be the only way out. In the new strategy, Ethiopia aims to reduce GHG emissions to $250 \mathrm{Mt}$ CO2e in 2030 (FDRE 2011).

The four pillars identified to develop the green economy strategy include improvement of crop and livestock production practices, protection and reestablishment of forests for their carbon stocks and other ecosystem services, the expansion of electric power generation from renewable sources for local and regional markets, and the transition to modern energy-efficient technologies in transport, industry and buildings (FDRE 2011, 20). The exploitation of the vast hydropower potential, large scale promotion of rural cooking technologies, efficiency improvements to the livestock value chain and reduction of emissions from Deforestation and Forest Degradation (REDD) are selected for fast track implementation in this Strategy (FDRE 2011, 3). Ethiopia has already started to pursue green economy initiatives, including the National Clean Cook Stove Program Ethiopia, clean energy and wind power investments particularly in Tigray and Oromia regions, the National Biogas Program for Ethiopia (NBPE), ethanol production, community forest and development (for instance, the Humbo Mountain Communitybased Natural Regeneration Project), the Sustainable Land Management (SLM) programme, among others. Local communities in Humbo have been supported to restore degraded native forests (2728 hectares) through farmer-managed natural regeneration under the clean development mechanism (Brown et. al. 2011).

It is noteworthy that $90 \%$ of Ethiopia's electricity comes from renewable sources, mainly from hydro power (FDRE 2011, 13). It is expected that the completion of the Grand Millennium/Renaissance dam will satisfy Ethiopia's need for hydropower. The government has planned to exploit hydro, geothermal, solar and wind power. It has also embarked on afforestation and reforestation programmes in different parts of the country, including the Great Rift Valley. Furthermore, Ethiopia aims to reduce emissions from the livestock sector by up to $45 \mathrm{Mt} \mathrm{CO2e} \mathrm{per} \mathrm{year} \mathrm{by} 2030$ (FDRE 2011, 53). Currently, 11\% of the country's GDP comes from livestock (FDRE 2011, 50 ), and the contribution of this sector to GHG emissions is very high. 
After considering Ethiopia's Climate-Resilient Green Economy (CRGE) strategy, one can say that Ethiopia understands its ethical obligation to mitigate climate change. Although this strategy does not directly raise ethical issues, some of its objectives are ethically acceptable and defensible. Thus one can say that the CRGE is a very environmentally friendly and ethically acceptable policy initiative. It emphasises the key role of climate change adaptation and mitigation measures to attain a green economy. However, this strategy does not benefit from climate ethics. The government did not acknowledge that Ethiopia's climate policies need to be guided by ethical principles. Likewise, the climate change adaptation policy programmes of various national states in the country did not mention ethical issues in their programmes (see EEPA 2011).

Another major challenge is the implementation of the Climate-Resilient Green Economy (CRGE) policy objectives. The first major problem is financial constraint. The government hopes that its ambitious plans will be supported by bilateral and multilateral development partners, as well as by the private and public sectors. However, as I argued elsewhere (Kelbessa 2014), the Ethiopian government cannot fully implement its environmental policy because of its top-down approach, weak capacity in environmental management and enforcement, lack of manpower and womanpower, inadequate finances and infrastructure, conflict between local community interests and state objectives about resource management, lack of clear operational guidelines on how to implement people's participation in environmental management, among others (EEPA 2008; Keeley and Scoones 2003, cited in Kelbessa 2014). Moreover, there are no mechanisms in Ethiopia for citizens, NGOs and other interested organisations to question/contest the nation's ethical position on climate change. The government has continued to use a top-down approach to implement its programmes. The public ought to be involved in the implementation of the CRGE. In addition, the actual implementation of the CRGE requires the development of institutional capacities and human resources. It remains to be seen whether the ambitious policy objectives of the CRGE will have positive results. 


\section{Climate Policy in Kenya}

Kenya ratified the United Nations Framework Convention on Climate Change (UNFCCC) in 1994, and endorsed the Kyoto Protocol in 2005. After developing a National Climate Change Response Strategy in 2010, she launched the National Climate Change Action Plan (NCCAP) 2013-2017 in 2012 (Government of Kenya 2013). This Action Plan is designed to guide the transition of the country towards a low carbon climate resilient development pathway. Individuals, Civil Society Organisations (CSOs) and other interested parties participated in the preparation of the National Climate Change Response Strategy (Oulu 2014, 91). Kenya is determined to undertake emissions reduction actions in its plan. It has identified the promotion of energy efficiency and renewable energy technologies, as well as tree planting as important mitigation measures. However, just as Ethiopia, Kenyan climate policy makers did not explicitly address ethical issues.

\section{Climate Policy in Uganda}

Uganda is a party to UNFCCC and the Kyoto Protocol. Its National Development Plan (NDP) was designed to promote low carbon development (Andrew 2014, 150). A Climate Change Unit, an institutional framework for the Clean Development Mechanism, a Climate Change Policy Committee, and an Inter-institutional Climate Change Technical Committee were established by the Ugandan Government in 2008 (Andrew 2014). The country proposed its Nationally Appropriate Mitigation Actions (NAMAs) to control emissions in the energy, transport, agriculture and waste sectors. Among other measures, Uganda has introduced solar energy to reduce GHG emissions (Andrew 2014, 149).

In spite of taking some preliminary steps towards the mitigation of climate change, the Ugandan government has not yet put in place concrete measures to reduce GHG emissions. It has not done much about recycling, healthy urban transport, and the sources of renewable energy. Thus as Andrew noted, "Uganda, like many other developing countries, has not taken considerations of ethics and justice into account in developing national policy and law" (Andrew 2014, 151). Andrew $(2014,153)$ states 
that the public cannot challenge the government, as there has never been a conducive environment for the general public to influence climate change policies.

\section{Climate Policy in South Africa}

South Africa is the highest GHG emitter in Africa, and coal is the backbone of the South African economy. The electricity sector, the metals industry and the transport sector produce about $80 \%$ of the country's $\mathrm{CO}_{2}$ emissions (Perrot 2014, 125). In 1996, South Africa established a National Climate Change Coordinating Committee (NCCC), which facilitates discussion and dissemination of information on environmental issues (Perrot 2014, 128). The South African government also encourages the public to debate on various policy issues including climate change. Section 24 of the Constitution of the Republic of South Africa (1996) recognizes the right of the people to a decent environment and to protection for the benefit of present and future generations. According to the National Environmental Management Act (NEMA) of South Africa, "environmental justice must be pursued so that adverse environmental impacts shall not be distributed in such a manner as to unfairly discriminate against any person, particularly vulnerable and disadvantaged persons" (quoted in Perrot 2014, 128).

The South African government ratified the UNFCCC and the Kyoto Protocol in 1997 and 2002 respectively. South Africa has indicated its willingness to reduce its GHG emissions consistent with its fair share of safe global emissions. It has also expressed its right to foster economic development and address poverty in the country. During the 2009 Copenhagen climate change negotiations, the government of South Africa undertook to reduce domestic GHG emissions by $34 \%$ by 2020 and $42 \%$ by 2025 (Perrot 2014, 123). It is also worth noting that four large newly industrialized countries (Brazil, South Africa, India and China) formed a group called "BASIC Countries" in 2009 (Bidwai 2014). They wanted to air their views together during the 2009 Copenhagen climate summit.

South Africa announced its National Climate Change Response (NCCR) policy in 2011 at the Conference of Parties (COP 17) in Durban, South Africa. The country's response to climate change is designed to meet two objectives: to deal with the 
impacts of climate change and to make "a fair contribution to the global effort to stabilise greenhouse gas (GHG) concentrations in the atmosphere" (NCCR 2004). In addition, South Africa tries to use climate change policy to respond to the needs of poor and vulnerable people in the country. Provincial and national governments in South Africa have formulated climate change response strategies and action plans (Perrot 2014). This is one of the best examples of national responses to climate change for both developed and developing countries. However, large mining companies and industries have sometimes manipulated other stakeholders and diverted policies to their own advantage in South Africa (Perrot 2014, 131), so the government ought to be vigilant in order to prevent such manipulation in future.

It is clear that unlike other African countries, South Africa has paid attention to ethical issues in its constitution, as well as in its climate change response strategies and action plans. Nevertheless, there is no mention of ubuntu (see below) and other indigenous African ethical principles in its policies. Similarly, ubuntu was not included in the South African Constitution. There are two parts of the South African Constitution: the 1993 Interim Constitution and the Constitution of the Republic of South Africa Act 108 of 1996. The concept "ubuntu" appears in the post-amble of the 1993 Interim constitution. However, according to the standard interpretation of the constitution, what appears in the preamble or the post-amble is not part of the law. Thus ubuntu became a footnote in the 1993 Interim Constitution. In the 1996 Constitution, ubuntu is nowhere. In personal communication with Mogobe B. Ramose (2015), he indicated to me that this is a deliberate exclusion. In the current legal system, the constitution is the supreme law and is not amenable to flexibility and interrogation. This absolute constitution refrained from recognising the principle that the people are sovereign. It is thus incompatible with the ubuntu principle that everything is in motion. Under the current constitution, no one can appropriate the private property of individuals, including land. According to Ramose, the South African constitution is a gentlemen's agreement to continue apartheid. It should be stressed that ubuntu has a role to alert all stakeholders to take ethical stands when they deal with climate change and other environmental issues. 


\section{Climate Policy in Nigeria}

Like Ethiopia, Kenya and Uganda, Nigeria is a party to the UNFCCC and the Kyoto Protocol. The Nigerian Federal Government aims to make Nigeria carbon neutral by 2025. It has taken certain measures to tackle the challenges of climate change. It established the Federal Ministry of Environment in 1999. This Ministry includes the Department of Climate Change which coordinates national climate change efforts. Nigeria has already put the National Policy on Climate Change and Response Strategy (NPCC-RS) in place. It has also established the Science Committee on Climate Change to study the connection between scientific knowledge and climate policy (Corsi et. al. 2012). The government has also established a National Adaptation Strategy and Plan of Action on Climate Change for Nigeria (NASPA-CCN). Furthermore, it formulated strategies for each of the following priority sectors: agriculture (crops and livestock); freshwater resources, coastal water resources and fisheries; forests; biodiversity, health and sanitation; human settlements and housing; energy; transportation and communications; industry and commerce; disaster, migration and security; livelihoods; vulnerable groups; education (BNRCC 2011, vviii, 35-58). A Strategic Framework for Voluntary Nationally Appropriate Mitigation Action (NAMA) (BNRCC 2011, 25), and a National Climate Change Policy for Nigeria are being developed.

The National Adaptation Strategy and Plan of Action on Climate Change for Nigeria is based on anthropocentric concerns (see BNRCC 2011, 32). There is no mention of the well-being of non-human species. Thus one can say that climate related strategies in Nigeria were not guided by ethical principles related to non-human animals and the natural environment. Yet the National Adaptation Strategy and Plan of Action on Climate Change for Nigeria (NASPA-CCN) made reference to the responsibility of developed countries to support developing nations (BNRCC 2011, 5). However, there are no explicit ethical principles designed to check the activities of the major international and national oil companies operating in Nigeria.

Six major international oil companies - Shell, Mobil, Chevron, Agia, Elf and Texaco and other multinational companies are operating in the country. These companies do not meet the required ethical standards. They bribe state officials and externalise 
environmental and social costs in Nigeria. Some Nigerian government officials have acknowledged this problem (Frynas 2000, 22).

Furthermore, the people living in the Niger Delta have not benefited from their resources. Oil companies have not contributed to employment, improvement of roads, hospitals, schools and environmental rehabilitation. Oil industry activities, such as exploration, production, refining and transportation have caused widespread social and ecological disturbances in the Niger Delta. These include explosions from seismic surveys, pollution from pipeline leaks, blowouts, refinery effluents, as well as land alienation and widespread disruption of natural terrain from construction of oil-related industrial infrastructure and installations (Hutchful 1985). In particular, gas flaring has had negative impacts on local communities, human health, socio-economic environment, and the natural environment in Nigeria. It has been one of the causes of water and air pollution. Aniefiok E. Ite's and Udo J. Ibok's review of various works on the subject showed that petroleum-associated gas flaring and venting systems in the oil-producing Niger Delta had the following effects: greenhouse effect, increase in temperature or thermal gradient, poor human health quality, poor agricultural yields, acid rain/acidification of aquatic environment, and changes in the ecosystem (Ite and Ibok 2013, 72). The soils are being acidified by atmospheric contaminants associated with gas flaring. In the Niger Delta, air pollutants have become causes of cancer, neurological, reproductive and developmental problems, deformities in children, lung damage and skin problems (Ovuaporaye et. al. 2012, cited in Ajugwo 2013, 7).

The Niger Delta's GHG emissions are higher than those of other states because of gas flaring within the oil industry. Gas flaring and venting systems in the oil-producing Niger Delta have contributed to GHG emissions and airborne contaminants (Ite and Ibok 2013, 71). After removing the natural gas called "associated gas" from oil, oil firms burn the former or they release it into the atmosphere through venting. Oil companies do not re-inject the gas into the oil wells, preferring instead to flare it and pay insignificant fines. The exploration of oil in the Niger Delta has led to the flaring of 17.2 billion $\mathrm{m}^{3}$ of natural gas per year (Ajugwo 2013,6).

The Nigerian government has had laws in place since 1979 to regulate gas flaring in the petroleum sector, and "by the 1979 Associated Gas Re-injection Act, no oil 
company was permitted to flare gas after January 1984 without ministerial authorization" (Ite and Ibok 2013, 70). However, the government did not enforce these flaring policies and regulations. In fact, the Delta State has designed strategies to integrate adaptation and mitigation for low-carbon climate-resilient development (UNDP 2011).

\section{Overview}

In general, although the above-mentioned and other African countries have already initiated governance systems for adaptation and mitigation, they have limited resources, fragmented institutional frameworks, a low resilience and limited adaptive capacity to address climate-related shocks and stresses. There have been very weak policy linkages among regional, national, and sub-national climate policies. In addition, policies have not been effectively implemented because of financial constraints and low levels of adaptive capacity. Although some of the abovementioned African countries have set meaningful GHG emissions targets, they have explicitly stated that to fully achieve some of the climate goals they need funding from developed nations. Furthermore, the climate policies of the above-mentioned countries were primarily designed to protect human interests. The well-being of nonhuman life forms and the natural environment was not their focus, despite the appearance in them of some terms such as "green economy" and "sustainable development".

The environmental and climate policies of the aforementioned countries have identified the importance of people's local participation in planning, management and decision-making. They recognize that citizens are agents of change, and that environmental degradation has not only local origins, but also local solutions. However, they fall far short of clarifying the legitimate forums and forms of popular participation. They have also barely addressed the role of civil society organisations through which individual members of a society can galvanize their efforts, achieve change, articulate their interests and exercise their rights in addressing issues of environment and climate change. Thus local communities are not yet active participants in the design and implementation of environmental and climate policies in these countries. 


\section{Climate Ethics and African Ethics}

As stated earlier, climate ethicists have emphasised the need for addressing the moral aspects of climate change. A full discussion of the views of different climate ethicists would be quite interesting, but cannot be pursued here. I will focus on some ethical principles that can have an impact on climate policy. I will show how the ethical principles suggested by climate ethicists and African ethics can best help humanity to deal with the challenges of climate change. I will argue that some of the ethical principles stressed by climate ethicists have already been developed and used by various cultural groups in Africa.

The major ethical principles embodied in different African traditions can assist African and non-African nations to address the challenges of climate change. One of these principles is inter-generational justice. African worldviews include intergenerational ethics that teaches that natural resources ought not to be exploited beyond limit, and that the land ought to be taken care of for the benefit of present and future human generations, as well as for the good of non-human species. In many African societies, the members of the clan include the unborn, those living in the world of ordinary sense experience, and those living in the post-mortem world of the ancestors. According to the African worldview, currently living human and nonhuman beings, the living dead, the yet unborn, and the natural world are interconnected. For many African communities, it would be wrong to over-consume resources and leave future generations with fewer means of survival. Thus for these societies, the current generation has moral obligations towards future generations as they are morally considerable. This principle can be applied to the issue of a conducive climate, which is the right of both present and future generations. Climate ethics also endorses this principle (see Arnold 2011; Gardiner 2011).

Some philosophers lay emphasis on the non-identity problem - a term which refers to the fact that in some cases the actions of the present generation have an effect on the identity of future generations. Some writers doubt if the current generation can stand in any kind of morally relevant relationship with future beings if the very existence and individuality of those beings is affected by the actions of the present generation. 
They think that we cannot base our policy on the interests of particular individuals because their identity is not yet determined. However, the "non-identity problem" is not a serious challenge to the African conception of inter-generational justice.

According to indigenous African thought, the present generation is under obligation to the past (the living dead) and future generations (Wiredu 1994). Munyaradzi Felix Murove (2004), a Zimbabwean scholar, in his work on ukama (relationality), holds a similar view. In Africa, people have direct and indirect obligations to future generations. In the first place, the land belongs communally to past, present and future generations. Individuals may privately possess livestock and movable possessions (van Rooy 1997, 102). In contrast to this, under customary rights, the land belongs to a clan or a descent group. As stated earlier, the current generation ought to preserve the environment for future generations. In the second place, the current generation ought to be grateful to, and follow the example of, past generations with regard to leaving behind a healthy land. This indicates an indirect moral obligation towards future generations. According to Kevin Gary Behrens, "[i]t is likely that this backward-looking notion of duties to posterity is one of the most significant contributions African thought can make to our conception of moral obligations to the future" (Behrens 2012, 187).

It is worth noting that African ethics does not require the current generation to pay attention to the rights and interests of future individuals, but rather those of future communities. Accordingly, there is no need to know the exact nature and demands of autonomous individuals, as the focus is on groups, that is, generational communities. Thus the present generation can have obligations towards whoever will constitute members of communities in future generations. Thus the Oromo of Ethiopia (the largest ethnic group in the country) believe that we know enough about the welfare of future persons to act responsibly on their behalf, because like present persons, future persons are human beings and need a healthy environment (Kelbessa 2011). Consequently, those countries that irresponsibly aggravate climate change ought to learn from the ethical principle which highlights the intergenerational dimensions of global climate change and pay attention to the well-being of future generations over and above their current interests. 
African environmental ethics recognises the proper place of non-human animals in the world, and the relatedness among human and non-human beings on the one hand and the environment on the other. Like human beings, non-human animals have the right to exist. Africans are committed to the preservation of all species (Kelbessa 2014). For instance, Oromo environmental ethics teaches that it would be wrong to destroy a species, as it would reduce the creation of God which can never be replaced. Nevertheless, reducing the number of harmful animals short of extinction is acceptable. The Oromo people believe that like human beings, animals have the right to live and drink water. It would therefore be unethical to kill wild animals at water points. Thus the Borana Oromo deliberately leave water behind around wells for wild animals to drink in the night. In this regard, we should note that climate change has intra and inter-generational justice dimensions because it places both present and future human and non-human generations in jeopardy. Climate change involves issues of equity both between generations and species.

Sirkku Hellsten et. al. also suggest that to complete the transformation to a postcarbon, sustainable, and resilient world, we should return to the communitarian approach that is based on African philosophy. They stress that climate ethics can benefit greatly by incorporating the communal dimension of African tradition that "is clearly articulated in African sagacity" (Hellsten et. al. 2013, 98). They further argue that "[i]f well-articulated, properly substantiated, and readily available to community members especially in urban areas, sagacity could serve as a check on our selfcentered and risky belief in the saving graces of technology" (Hellsten et. al. 2013, 100). For my part, I am not prepared to accept the view that all African sages are environmentally friendly and can contribute to solving the climate change problem. Although sages are familiar with the communal knowledge of their people, in some cases they can contribute to environmental degradation for various reasons. They may not understand the causes and effects of climate change. In spite of this, I think that the ethical views of some indigenous environmental sages can contribute to addressing climate change, influence consumer societies to transform their culture and move to a new ethos of responsibility, care, and natural integration.

The philosophy of ubuntu can also offer useful lessons for human beings. The concept of ubuntu, found in the Bantu languages of East, Central and Southern Africa, 
captures the essence of what it means to be human (for details see Tutu 1999; Ramose 2002; Murove 2004; Munyaka and Motlhabi 2009). It affirms that a person is a person through other persons, and I am what I am because of what we all are. We affirm our humanity when we acknowledge that of others: no single individual is complete without the others. For ubuntu philosophy, the conception of persons is centrally constituted by and through their relations to others. These relations inform a person's understanding of moral behaviour and how to live in a community.

Mogobe B. Ramose (2002) presents a philosophical interpretation of ubuntu. He approaches the term ubuntu as a hyphenated word, ubu-ntu. He holds that from a philosophical point of view, it is a compound word containing the prefix $u b u$-and the stem $n t u$-. Ubu- is the highest level of generality in ontological terms, in terms of being. The second aspect is the point that it $(u b u)$ is hanging, it is in motion, in perpetual suspension.

When we couple $u b u$ - with $n t u$-, we couple it with something normative in the sense that it has also an ontological reference. The words $u m u$ - and $u b u$ - share an identical ontological feature. Unlike $u b u$-, ити- inclines "towards the more specific". Umu- can also be coupled with $n t u$, then it becomes umuntu. "Umuntu means the emergence of homo-loquens who is simultaneously a homo sapiens. In common parlance it means the human be-ing: the maker of politics, religion and law" (Ramose 2002, 41). Umuntu has an obligation to become ethical. To be a human being is to be umuntu. The speech of umuntu leads the epistemological domain towards the ontology of $u b u$ by conjoining "ubu- and umuntu through the maxim umuntu ngumuntu nga bantu (motho ke motho ka batho)" (Ramose 2003, 272). This is translated as "a person is a person through other persons".

Ubuntu philosophy recognizes both entitlements and obligations towards others. An individual who needs help should be supported by those who can provide it, as the latter have "a duty and obligation to render services" (Munyaka and Motlhabi 2009, 82). Developed nations who are reluctant to reduce their greenhouse emissions should learn from this principle and support poor countries to develop and address the adverse effects of climate change. As S. Biko correctly explained, ubuntu would be a 
"special contribution to the world in the field of human relations", "giving the world a more human face" (Biko 1978, 47, quoted in Munyaka and Motlhabi 2009, 83).

Furthermore, the principle of ubuntu can be extended to the biotic community. Ubuntu transcends individualism which is common in the Western world. Its ethical message is not restricted to one's own ethnic group, regional community or nation, but can cover all of humanity and the more-than human world. This standpoint is succinctly stated by Ramose. He stresses that the fulfillment of natural duty includes caring for one another and for the natural environment (Ramose 2002, 124).

On his part, Kwame Gyekye emphasises the importance of "generosity" or what he calls "supererogatory acts" in many African communities. "A supererogatory act is defined as an act that is said to be 'beyond the call of duty'; it is an act that is said to be over and above what a person is required to do as a moral agent" (Gyekye 2013, 235). Super in Latin means "above". Gyekye thinks that supererogatory acts are intrinsic to a communitarian ethic which requires an individual to give greater attention to others and less attention to himself or herself. Morality commends supererogatory acts where individuals pay regard to the interests of others. This is an important moral responsibility in many African societies. As shown above, the word ubuntu is also intrinsic to a community-oriented outlook and has a similar message.

However, it should be noted that it is not always possible to observe these ethical principles. There have been many instances where Africans have violated their ethical principles because of internal and external factors (Munyaka and Motlhabi 2009, 81; Tutu 1999, 36).

Climate ethics also suggests that developed countries ought to assist developing countries to mitigate and adapt to climate change. The current generation has obligations to future generations whatever their identity turns out to be. One of these obligations is that where avoidable, the present generation ought to refrain from reducing the quality of the life of future generations - an obligation we are currently neglecting through greenhouse gas emissions. 
Climate justice requires that developed countries, that are the major cause of climate change, be accountable and pay their fair share for what their past and current generations have done to the global climate, and also play their appropriate role in averting the most extreme risks of climate change. Although some philosophers agree among themselves that developed countries ought to take the lead role in bearing the costs of climate change, they remain divided on the actual responsibilities of those countries. They have proposed different ethical principles, including historical principles, equity or fairness, global emissions trading, a system of international pollution permits and the like to deal with climate change (Steidlmere 1999; Singer 2002; Jamieson 2003).

Peter Singer (2002) examined the ethical principle of equity or fairness. Although he stressed that the principle of an equal share for everyone is fair, he persuasively showed that the strict egalitarian principle is indefensible, as it implies that equality can be achieved by " 'leveling down,' that is, by bringing the rich down to the level of the poor without improving the position of the poor" $(2002,37)$.

Another area of contention is the application of historical principles that take past emissions into account. Accordingly, one can argue that the developed countries that have caused pollution have historical responsibility to pay: this is known as the Polluter Pays Principle (PPP). There are arguments against and for this position (OECD 1997; Shue 1999; Neumayer 2000).

Some writers suggest that children born recently should not pay for what their ancestors did. For instance, Simon Caney argues that it would be unfair and inadequate to apply the "Polluter Pays Principle" to climate change, as some actual individual polluters are dead and cannot pay (Caney 2010a, 122-145; see also Bell 2013 , 207). Caney is of the opinion that the polluter pays principle is not a complete principle of justice, as it cannot be applied to present and past generations, because the former is not responsible for climate change and the latter may not have been aware of the harmful effects of GHG emissions on the climate. Accordingly, Caney is against historical responsibility with regard to pre-1990 emissions. He has asserted that if the polluter is not aware of the negative consequences of his/her action, his/her ignorance is excusable (Caney 2010a, 130). However, one can reasonably question 
this position, as the current generation has enjoyed the wealth created because of the emissions by past generations. As Henry Shue observes, "current generations are, and future generations probably will be, continuing beneficiaries of earlier industrial activity" (Shue 1999, 536; see also Neumayer 2000, 189).

However, Caney is determined to oppose the beneficiary pays principle. He proposes what he calls the hybrid account that accommodates the "polluter pays" approach, and an "ability to pay" approach that requires the most advantaged to handle the problem of climate change. He states that the hybrid account does not make states responsible for the decisions of earlier generations. He suggests that affluent persons rather than affluent countries in the world should bear the responsibility of dealing with climate change (Caney 2010a, 137). Although I believe that high-emitting individuals and organisations in both developed and developing countries have responsibilities to minimize their GHG emissions, Caney's proposal that seems to exempt the governments of developed countries is not persuasive. He should have understood the difference between the standard of living in industrialized and non-industrialized countries. The current high levels of prosperity in the developed world are based on cumulative emissions of greenhouse gases. As such, it would be unethical for developed countries to neglect their responsibility. Governments, and particularly the governments of developed countries, bear the prime responsibility. I also think that many individuals have responsibilities, as citizens, to set personal examples and to try to persuade their governments to act in these ways.

Although Singer (2002) and Jamieson (2001) do not totally ignore historical responsibility for past emissions, they think that ignorance is responsible for emissions prior to 1990, as it was not well established that greenhouse gases would lead to climate change. Although Singer is aware that "backward-looking principles" are relevant, he thinks that poor countries might "generously" ignore historical responsibility. However, Gardiner does not agree with this position, as he doubts the extent to which the ignorance defense is applicable. He stresses that the rich nations bear a special responsibility to assist poor nations who have no means to defend themselves against the consequences of climate change (Gardiner 2004, 583). Similarly, I strongly suggest that developed countries ought to give assistance to developing ones for adapting to climate change. Without significant international 
assistance, the most vulnerable countries will be in a difficult situation with regard to adapting to the impacts of climate change. Formulation of climate friendly policies does not make sense if countries cannot realise their objectives because of lack of technical and material resources.

On their part, Andrew Light and Gwynne Tarska (2014) suggest that "climate change provides a relationship of harm". They observe that greenhouse gases have been produced largely by the developed world, yet these gases harm people in the developing world. As such, the latter should get adaptation assistance from the former - assistance which they refer to as "climate-ready development assistance". Thus they think that the traditional argument for development assistance can be extended to include climate adaptation assistance. However, I hold the view that the "responsibility" which lies on rich classes and nations to create justice does not necessarily presuppose guilt: one can talk about responsibility without referring to guilt or past wrongs such as systematic violations of human rights and other forms of social and environmental injustice.

Enlightened self-interest can also encourage developed nations to contribute to climate change mitigation and adaptation. A world in which all lead a decent life is a safer world than one in which only a few do while hundreds of millions of people suffer from the negative consequences of climate change. Thus their long term security can motivate developed nations to take further steps to address climate change.

As earlier indicated, climate ethics supports the view that all nations ought to reduce their emissions to their fair share of safe global greenhouse gas emissions. However, it is currently difficult to expect all developing countries, particularly the very poor ones, to reduce their GHG emissions. This is due to the fact that such countries ought to be allowed to continue to emit greenhouse gases in order to improve their economies and thus satisfy the basic needs of their people. As stated earlier, wealthy nations should be more responsible to mitigate climate change. This responsibility will change over time. As the UNFCCC (1992) suggested, the principle of common but differentiated responsibilities is relevant. 
As Shue (1993) suggested, nations ought to try to eliminate emissions generated for luxury uses rather than to meet "subsistence" needs. Shue made a distinction between "subsistence" (or "survival") and "luxury" emissions. Subsistence emissions may include meeting one's basic needs, heating one's home and the like, whereas luxury emissions may include driving large and relatively energy-inefficient vehicles, taking exotic vacations far from home and the like. Luxury emissions are connected to the excesses of modern life whose absence does not threaten human well-being and decency. Thus as Shue suggests, it is advisable to reduce unnecessary energy use. J.P. Sterba (2009) also stresses that the poor should have priority to meet their basic needs before the rich meet their wants for luxury goods. Lifestyle and behaviour changes, at least in developed countries, can play a significant role in reducing greenhouse gas emissions in the short-term (Dernbach and Brown 2009, 1004), as households, for instance in the U.S., directly control one third of the energy consumed (Stern and Gardiner 1981, cited in Dernbach and Brown 2009, 1003). The IPCC has also recognized the positive impact of behaviour and lifestyle change on energy use (IPCC 2014b, 20).

However, some writers argue that during the transition to a lower carbon economy, developed countries ought not to be required to reduce their GHG emissions more than developing nations, nor ought they to have low entitlements. In other words, they suggest ignoring historical responsibility and propose an alternative historical view, namely, “'grandfathering' of emissions, suggesting that past emissions strengthen the claim for future entitlements" (Knight 2014, 572; emphasis in original). Carl Knight defends moderate grandfathering. He thinks that historical responsibility is not the right way to deal with climate change, as "members of countries with high historical emissions are typically burdened with higher costs, when transitioning to a given reduced level of emissions, than are members of otherwise similar countries with lower historical emissions" (Knight 2014, 572). According to Knight, past high emissions can be used as a justification for an agent to have high entitlements. He argues that when high emitters reduce their emissions, their costs will be higher than those of the lower emitters. He is of the opinion that emission limits in poor countries will not have drastic consequences because their dependence on emissions is insignificant, thus the need for a moderate form of grandfathering. 
Unlike Simon Caney (2009, cited in Knight 2014, 589) who considers grandfathering to be unjust, I think that Knight's proposals have some merits. As he said, during the transition to a low carbon budget, firms, households and governments can have high costs when they reduce GHG emissions. Some commodities can be expensive or disappear from the market. In other words, a radical cut in emissions may have a negative impact on the current generation. Nevertheless, this should not be taken as an excuse to exempt high emitters from reducing their emissions. The full application of grandfathering (free allocation of permits) is indefensible. I suggest that some measures be taken to reduce the harm that may be caused to the people of high emitting countries during the initial transition to a low carbon budget in consultation with other countries.

Although developing countries need high fossil fuel energy production and consumption to pursue sustainable development, they also ought to aim to reduce their greenhouse gas emissions by employing energy efficiency and alternative sources of energy. Even though they do not exceed their fair share of safe global emissions, they ought to try to reduce their emissions when they can do so (Dernbach and Brown 2009, 1003). Emission reduction targets by developed countries alone are not sufficient to address the problem of climate change: developing countries also have responsibilities to reduce their GHG emissions, as they have continued to contribute to global warming. It is important to bear in mind that any person who overexploits fossil fuels contributes to climate change, even if the negative impact might not be quantified each time.

The ethical solution to the problem of climate change is stopping or reducing what we have been doing and compensating those harmed by our actions. Thus newly emerging economies (China, India, Brazil, South Africa and South Korea), and other developing countries ought to participate in the reduction of greenhouse gas emissions through measures such as green technology and afforestation. As earlier indicated, South Africa and Ethiopia have taken positive steps in this regard.

Another important principle upheld by African ethics that can help humanity address the problem of climate change is "Do No Harm". For instance, in ubuntu societies, it would be unethical to promote one's interest at the expense of others. One ought to be 
happy when others are happy rather than when they are unhappy. Similarly, saffuu, ${ }^{2}$ an ethical principle in Oromo society, regulates people's activities and the use of natural resources (Kelbessa 2014, 40). According to the Oromo ethic, one ought not to unnecessarily harm fellow human beings and the natural environment.

As stated earlier, highly industrialised nations have been harming the people in the developing world by emitting high levels of GHGs. They therefore ought to acknowledge their global responsibility to refrain from harming others. It is true that humanity cannot stop using fossil fuels within a short period of time, but it can reduce their environmental impact through a lifestyle change. Do No harm principle, also stated in the United Nations Framework Convention on Climate Change (UNFCCC 1992, Preamble), requires countries to refrain from harming people outside their jurisdiction. All cultural, religious and ethical groups accept the principle that it would be wrong to harm innocent human beings. We do not need any ethical theory to substantiate this view. "As it is theoretically uncommitted, the 'Do No Harm' principle is efficient on a practical level" (Rentmeester 2014, 15). Casey Rentmeester (2014) believes that positive change would come in our individual lives and in the fields of economics and politics if we subscribe to "the non-theoretical, crossdisciplinary, cross-cultural” Do-No-Harm principle.

African ethics also emphasises the principle "promote life and avoid killing". The ethical maxim of the Bantu-speaking peoples, namely, "feta kgomo o tshware motho" implies the primacy of this principle. For Ramose, the above mentioned maxim affirms the importance of human dignity. It indicates that a person who is required to choose from two alternatives, namely, the protection of one's wealth (symbolised by

\footnotetext{
${ }^{2}$ Saffuu, an ethical principle, governs the relationships between human beings and different entities. These relationships carry ethical obligations including the duty to respect mother Earth, pay attention to future generations, and the duty to remember and teach the ecological relationships. Good persons are required to be respectful. Stealing, milking animal during herding, drunkenness, the mindless destruction of our environment and other immoral acts are shameful.

${ }^{3}$ This maxim can be translated as "go past the cow and catch the human being". Kgomo stands for a cow, which is considered a status symbol of wealth. "Feta is the jussive or command verb obliging one to pass. In this sentence, the purpose of passing by is to go and get hold (tshware) of the human being (motho)" (Ramose 2013, 247).
} 
the cow) and the preservation of the life of another human being, ought to choose the latter: "Mutual care for one another as human beings precedes concern for the accumulation and safeguarding of wealth as though such a concern were an end in itself" (Ramose 2002, 127). Those who give priority to wealth ought to subscribe to this important principle by endeavouring to save the people who are in life threatening situations due to climate change and other challenges.

In the light of the foregoing observation, one can say that actions leading to climate change violate human dignity as recognised by African ethics. Many regard climate change as a human rights problem. Shue (1999), Stephen Humphreys (2009), Caney (2010b) and Derek Bell (2011) have argued that anthropogenic climate change has violated basic human rights. For Caney, climate change threatens the right to life, the right to health and the right to subsistence. The African Commission on Human and Peoples' Rights has also recognized the impacts of climate change on human rights in its Resolution on Climate Change and Human Rights and the Need to Study Its Impact in Africa (ACHPR/Res 153 XLV09; cited in Niang et. al. 2014, 1211).

Thus the protection of fundamental human rights requires that the challenge of climate change be adequately addressed. Donald Brown and Prue Taylor (2014) have correctly suggested that like regular reporting on human rights compliance, strategies ought to be formulated to report on matters of climate change in the light of the ethical and justice obligations of nations.

Local communities' responses to climate and environmental changes also have some useful ethical elements. Indigenous African forest management has a positive contribution towards curbing GHG emissions. For instance, the Shona and Oromo people believe that trees affect the patterns of climate (Chemhuru and Masaka 2010; Kelbessa 2011). Although this belief may not have been scientifically proven in those communities, we now know that trees are important as a carbon sink.

One may object that although both climate ethics and African ethics have many useful principles, they have never influenced the actual practice in the world, so that expressing the fact that all parties ought to act according to justifiable moral precepts does not lead to theoretical or practical progress. This point deserves serious attention. 
Many powerful countries and large economic interests are not willing to seriously address global climate change in spite of the fact that the UNFCCC currently has 197 parties and there are 192 parties to the Kyoto Protocol. They are not ready to confront the unsustainable lifestyles of their people. They have used various mechanisms to deny the real threat of global climate change, and have been successful in influencing public opinion in the developed world. Thus various international agreements aimed at addressing the problem have not yet positively influenced powerful nations, as they have been ignoring them without any serious consequences. Currently, there are no enforceable sanctions to convince them to respect international agreements.

Thus the annual Conferences of the Parties (COPs) have not yet produced legally binding and globally and ethically acceptable solutions to climate change. ${ }^{4}$ For instance, the 18th Conference of the Parties (COP 18) of the UNFCCC took place in Doha, Qatar from 26th November to 8th December 2012 (Conservation International 2012). Although much was expected from that conference, the overall outcome was unsatisfactory. Among others, the delegates did not agree on new funds to help poor countries adapt to climate change. In addition, the United States and China, the world's largest greenhouse gas emitters, did not accept the new agreement supported by other nations. One of the achievements of the Doha conference was agreement to a second commitment period under the Kyoto Protocol, which began on 1st January 2013 and ended on 31st December 2020. Thirty-seven countries (Australia, the European Union, and its 28 members, Belarus, Iceland, Kazakhstan, Liechtenstein, Norway, Monaco, Switzerland and Ukraine) have accepted obligatory emissions cuts during the second commitment period of the Kyoto Protocol. Most of them have ratified the Doha amendment establishing the second commitment period of the Kyoto Protocol (UNFCCC 2014b). The target for the second commitment period is to reduce emissions by at least 18\% below 1990 levels during the period 2013-2020 (Conservation International 2012, 2).

\footnotetext{
${ }^{4}$ The United Nations Framework Convention on Climate Change (UNFCCC) was adopted and opened for signatures during the 1992 United Nations Conference on Environment and Development in Rio de Janeiro, Brazil, and entered into force in 1994. The ultimate objective of the UNFCCC is to stabilize "greenhouse gas concentrations in the atmosphere at a level that would prevent dangerous anthropogenic interference with the climate system" (UNFCCC 1992, Article 2). All states that are parties to the Convention have met once a year since 1995 in the Conference of the Parties (COP) to assess "the implementation of the Convention" and negotiate a treaty to address the problem of climate change. The first COP meeting took place in Berlin, Germany in March, 1995. The meeting takes place in a different country every year.
} 
Although Japan, New Zealand, Russia and Canada participated in Kyoto's first commitment, they did not endorse the second commitment period (see Light et. al. 2012, 1). Canada withdrew from the Kyoto Protocol in 2012, while the United States has never ratified it (UNFCCC 2014a). Accordingly, the U.S. is not bound by any second-round targets. Until recently, like the United States, China and India have not been willing to ratify any treaty that would force them to reduce their GHG emissions. They have previously claimed that they have no historical responsibility for climate change, and therefore refrained from binding commitments.

Some writers hold that there have been serious challenges that make international climate negotiations fruitless. For example, according to Andrew Light (2011), the outcome in the United Nations Framework Convention on Climate Change (UNFCCC) has been blocked by the continued use of the consensus rule. The case in point was Bolivia's opposition to the "Cancun Agreements" and different forms of compromise. Light laments that no serious ethical study of this problem has taken place so far. I certainly understand that reaching an international agreement on global climate change can take a very long time because of the principle of consensus rather than majority rule in the United Nations system. Although this can be one of the contributing factors for the failure of the COPs to arrive at ethically acceptable solutions, it is not the determining factor. The major obstacle is the refusal of powerful countries to consider climate change as a matter deserving urgent attention. Many developed and developing countries formulate climate policies mainly on the basis of their national economic interests, paying inadequate attention to their ethical obligations and global responsibilities. For instance, the U.S. government and other governments have explicitly ignored ethical and justice considerations in their climate policies (Brown and Taylor 2014, xxi). However, economic and political responses alone to climate change are inadequate. That is why we should examine the ethical dimensions of climate change.

It should be noted that the final agreement reached in Paris during the 2015 United Nations Climate Change Conference (COP 21) was different from all previous climate agreements. The $21^{\text {st }}$ session of the Conference of the Parties took place in Paris, France from 30 November to 12 December 2015. The participants adopted the Paris 
Agreement to combat climate change. At least 55 countries, which together represent at least 55 percent of global greenhouse emissions, are required to ratify the Paris Agreement (UNFCCC 2015, Article 21, Para. 1, 23). States and regional economic integration organisations that are Parties to the Convention are expected to sign the Paris Agreement between 22 April 2016 and 21 April 2017 (UNFCCC 2015, Article 20, Para. 1, 22), and the Agreement is expected to enter into force in 2020.

Compared to previous agreements, the Paris Agreement is expected to have a positive impact on the fight against climate change, as it establishes a long term global framework to tackle the problem. Unlike previous attempted climate treaties, the US, China, India and all other negotiating countries have agreed to reduce their greenhouse gas emissions. The Paris Agreement aims to hold "the increase in the global average temperature to well below $2{ }^{\circ} \mathrm{C}$ above pre-industrial levels and pursuing efforts to limit the temperature increase to $1.5{ }^{\circ} \mathrm{C}$ above pre-industrial levels" (UNFCCC 2015, Article 2, Para. 1(a), 3). All countries have undertaken to meet the targets that they have set. The Paris Agreement requires all countries to prepare their own plans to reduce their greenhouse gas emissions and to report on greenhouse gas inventories and mitigation progress every five years, starting in 2020. The Agreement creates a transparent system of measuring, reporting and verifying emissions. According to the Paris Agreement,

[p]arties shall account for their nationally determined contributions [to the global response to climate change]. In accounting for anthropogenic emissions and removals corresponding to their nationally determined contributions, Parties shall promote environmental integrity, transparency, accuracy, completeness, comparability and consistency, and ensure the avoidance of double counting, in accordance with guidance adopted by the Conference of the Parties serving as the meeting of the Parties to the Paris Agreement (UNFCCC 2015, Article 4, Para. 13, 5).

Furthermore, developed countries undertook to give financial support to developing countries for adaptation, mitigation, monitoring, loss and damage. 
Moreover, before the December 2015 Paris meeting, the Obama administration undertook to reduce US CO2 emissions by $26 \%$ to $28 \%$ by 2025 below 2005 levels. However, these new US commitments have not yet been implemented, and even if they were to be fully implemented they would still not represent the US fair share of safe global emissions (Brown 2015). It remains to be seen whether the Obama administration's commitments will have the full support of US politicians and the public in the years to come. Another major concern is whether both developed and developing nations will honour the undertakings they made to cut GHG emissions during the Paris 2015 meeting.

Although we cannot tell with full certainty the foreseeable impacts of the Paris Agreement, we cannot ignore the fact that progress has been made in the areas of environment and climate change, but much more efforts are needed to address climate change in particular. Some positive developments are taking place in the background. As stated earlier, some developed countries, including the European Union, have started to translate international agreements into practice. We can build on this little progress and move on to examine and understand the foreseeable consequences of climate change. Human beings are sufficiently rational to think about global problems, including climate change. As such, climate ethicists and other concerned groups ought not to stop raising public awareness and influencing world leaders to take both factual and normative issues into account. If citizens are exposed to new evidence about climate change, they can change their minds and force their governments to take necessary measures to address the global problem of climate change. When politicians understand that climate change is real and will endanger their own people, they will be forced to act and cooperate with others.

\section{Conclusion}

Although the reality of climate change has been supported by scientific evidence and reflected in its effects on the lives of populations around the world, some corporations and scientists are determined to question climate science. Corporations have used various morally indefensible tactics to question the findings of this discipline. Moreover, some developed nations have ignored their ethical responsibilities because of narrow national interests. Similarly, with the exception of a few countries, climate 
policies in Africa have not been guided by ethical principles. The main driving forces have been economic interests, although some countries have recognized their international responsibilities to mitigate climate change.

As stated earlier, climate change is fundamentally an ethical problem. The world's poorest countries, that are not the major contributors to climate change, have been hit hardest by its effects. Prolonged drought and flooding have affected millions of people. Those who lack the resources to adapt and to find alternative sources of food and healthcare will suffer substantially from climate change. At the same time, the measures that can be taken to reduce greenhouse gas emissions can also have a negative impact on the poor by restricting their use of resources and their movement from one place to another. On the other hand, developed countries, which are the major contributors to global warming, are not the ones that suffer its consequences most severely. Consequently, developed nations should fulfil their obligations not only to their own citizens, but also to citizens of other countries who are being grossly and negatively affected by the harsh effects of climate change. This article suggests that when countries formulate climate policies they ought not to consider only their own economic interests, but also bear in mind their ethical obligations at both the local and global levels.

Furthermore, as the foregoing discussion indicates, climate change has intra- and inter-generational justice dimensions. The actions of the current generation will affect the life of future generations. It is equally true that climate change has already had a negative impact on the current generation, particularly in the developing world. Consequently, our concern is the interests of present and future generations of human and non-human beings.

Although climate ethicists discuss the ethical dimensions of climate change, most of them largely focus on particular ethical issues rather than on environmental policymaking, thereby robbing themselves of the opportunity to influence policy makers and the public. Environmental ethicists and civil society organisations ought to raise public awareness about the danger of climate change, and the attendant ethical issues: "The media, NGOs, education institutions, academia, businesses and other social 
actors must all become involved in lifting both public awareness and the ability of the public to engage in ethical critique and analysis" (Brown and Taylor 2014, xxvii).

However, we need to bear in mind that currently, corporations are controlling the media, and their campaign contributions influence legislation, particularly in the developed world. News organisations that depend on advertising revenue are not willing to offend a major source of funds. Even worse is the fact that mainstream media tend to overrepresent the views of climate skeptics (see Arnold 2011, 3; Fossil Free MIT 2014, 6).

I think that influencing the attitudes of the people, particularly in the developed world, by enabling them to understand the work of the Intergovernmental Panel on Climate Change and other scientific findings about climate change, can make a difference. Environmentally conscious people can push their respective governments to fulfil their obligations, particularly in democratic countries. If the concerned governments fail to do so, the public can remove them from office. Politicians are shortsighted: they give priority to the needs of the current generation rather than to the non-living human beings who cannot vote, as they want to be re-elected. The voting public can force politicians to pay attention to the well-being of future human and non-human generations. Thus we cannot argue that only governmental bodies rather than individuals can address the problem of climate change.

Moreover, the preceding discussion suggests that in addressing the problem of climate change, industrialized countries can learn from African ethics, as the African value system teaches what Jamieson $(2003,377)$ calls "the interconnectedness of life" on earth. According to the African worldview, it would be wrong to disturb the balance of nature and endanger the survival of God's creatures. This can be extended to protest against the pollution of the atmosphere that will have negative repercussions on the inter-connectedness of life. Thus among others, technological societies whose current GHG emissions most exceed their fair share of emissions ought to give attention to justice by playing their respective roles in averting the most extreme risks of climate change. 
Another important conclusion is that policy makers ought to engage with the local people on climate change from an ethical perspective. They ought to respect them and learn from their knowledge and practices. Africans ought to expose their children to environmentally friendly African values at a very early age to promote intra-and intergenerational equity. Furthermore, African countries ought to introduce effective adaptation and mitigation measures. As stated earlier, animal production is one of the major sources of global GHG emissions. Currently, many African countries keep lowyielding cattle. They ought to reduce livestock numbers and introduce other alternatives that can contribute to the mitigation of climate change. In developing countries, adopting a plant-based diet is arguably the most important step an individual can take towards reducing his or her contribution to climate change. In such countries, the growing middle class leads to an increasing demand for meat and other animal products, which should be a major concern to environmentalists. The contribution of livestock keeping to global climate change requires further research. 


\section{References}

Ajugwo, Anslem O. 2013. "Negative Effects of Gas Flaring: The Nigerian Experience". Journal of Environment Pollution and Human Health, Vol.1 No.1, pp.6-8.

Andrew, Akampurira. 2014. "Uganda's Consideration of Ethics and Justice Issues in Formulating Climate Policies". Brown, Donald and Prue Taylor eds. Ethics and Climate Change: A Study of National Commitments. Gland: IUCN, pp.149-157.

Arnold, Denis G. 2011. "Introduction: Climate Change and Ethics". Arnold, Denis G. ed. The Ethics of Global Climate Change. Cambridge: Cambridge University Press, pp.1-15.

Arrhenius, Svante. 1896. "On the Influence of Carbonic Acid in the Air upon the Temperature of the Ground". Philosophical Magazine, Vol.41 No.4, pp.237276.

Attfield, Robin. 2010. "Mediated Responsibilities, Global Warming, and the Scope of Ethics". Irwin, Ruth ed. Climate Change and Philosophy: Transformational Possibilities. London: Continuum International Publishing Group, pp.183-196.

--. 2014. Environmental Ethics: An Overview for the Twenty-First Century. $2^{\text {nd }}$ Ed. Cambridge: Polity Press.

Bell, Derek. 2011. "Does Anthropogenic Climate Change Violate Human Rights?" Critical Review of International Social and Political Philosophy, Vol.14 No.2, pp.99-124.

--. 2013. "How Should We Think about Climate Justice?" Environmental Ethics, Vol.35 No.2, pp.189-208.

Behrens, Kevin Gary. 2012. "Moral Obligations towards Future Generations in African Thought". Journal of Global Ethics, Vols.8 No.2-3, pp.179-191.

Bidwai, Praful. 2014. "The Emerging Economies and Climate Change: A Case Study of the BASIC Grouping". Shifting Power/ Critical Perspectives on Emerging Economies TNI Working Papers. https://www.tni.org/files/download/shifting_power-climate.pdf

Brown, D.R., P. Dettmann, T. Rinaudo, H. Tefera and A. Tofu. 2011. "Poverty Alleviation and Environmental Restoration Using the Clean Development Mechanism: a Case Study from Humbo, Ethiopia". Environmental Management, Vol.48 No.2, pp.322-333.

Brown, Donald A. 2011. "Ten Practical Policy Consequences of Acknowledging That Climate Change Is an Ethical Problem". ClimateEthics.org. http://rockblogs.psu.edu/climate/2011/08/ten-practical-policy-consequencesof-acknowledging-that-climate-change-is-an-ethical-problem.html

--. 2015. "Issues the Media has Poorly Dealt With About the Paris Climate Deal: The Enormity and Urgency of the Climate Threat that has been Exacerbated by Political Opposition to Climate Policies". http://ethicsandclimate.org/2015/12/28/the-damage-to-the-internationalcommunity-caused-by-the-political-opposition-to-climate-change-policiesthat-is-responsible-for-a-40-year-delay-in-responding-climate-change/ 
Brown, Donald and Prue Taylor. 2014. "Introduction". Brown, Donald and Prue Taylor eds. Ethics and Climate Change: A Study of National Commitments. Gland: IUCN, pp.xvii-xxx.

BNRCC (Building Nigeria's Response to Climate Change). 2011. "National Adaptation Strategy and Plan of Action on Climate Change for Nigeria (NASPA-CCN)". http://nigeriaclimatechange.org/naspa.pdf

Caney, Simon. 2010a. "Cosmopolitan Justice, Responsibility, and Global Climate Change". Gardiner, Stephen M. et. Al. eds. Climate Ethics: Essential Readings. New York: Oxford University Press, pp.122-145.

--. 2010b. "Climate Change, Human Rights, and Moral Thresholds". Gardiner, Stephen M et. Al. eds. Climate Ethics: Essential Readings. New York: Oxford University Press, pp.163-177.

--. 2011. "Climate Change, Energy Rights, and Equality". Arnold, Denis G. ed. The Ethics of Global Climate Change. Cambridge: Cambridge University Press, pp.77-103.

Chemhuru, Munamato and Dennis Masaka. 2010. "Taboos as Sources of Shona People's Environmental Ethics". Journal of Sustainable Development in Africa, Vol.12 No.7, pp. 121-133.

Conservation International. 2012. "Analysis from Conservation International of Doha Climate Negotiations Eighteenth meeting of the Conference of the Parties United Nations Framework Convention on Climate Change (UNFCCC) 26 November - 8 December, 2012 Doha, Qatar". http://www.conservation.org/publications/Documents/CI_analysis_Doha_Outc omes_2012_26Nov-8Dec.pdf

Corsi, M., S. Hagemann and C. Salgado Silva. 2012. "Africa Adaptation Programme Third Quarterly Report 2012”. Prepared by the AAP Inter-Regional Technical Support Component, UNDP Africa Adaptation Programme, UNDP, New York, USA.

Coward, H. and T. Hurka. 1993. Ethics and Climate Change: The Greenhouse Effect. Ontario: Wilfred Laurier University Press.

Dernbach, John C. and Donald A. Brown. 2009. "The Ethical Responsibility to reduce Energy Consumption". HOFSTRA LAW REVIEW, Vol.37 No.985, pp.9851006.

EEPA (Ethiopian Environmental Protection Authority). 2011. "Regional Climate Change Adaptation Programmes". http://www.epa.gov.et/Download/Forms/AllItems.aspx?RootFolder=\%2FDow nload\%2FClimate \%2FRegional\%20Climate\%20Change\%20Adaptation \%20P rogrammes \&FolderCTID $=\&$ View $=\{73954 \mathrm{D} 8 \mathrm{C}-0691-42 \mathrm{E} 2-\mathrm{A} 1 \mathrm{~B} 1-$ D4A40994B2B0

FDRE (Federal Democratic Republic of Ethiopia). 2011. "Ethiopia's ClimateResilient Green Economy: Green Economy Strategy". http://www.greengrowthknowledge.org/sites/default/files/downloads/resource/ Ethiopia_Climate Resilient_Green_Economy_Ethiopia.pdf 
Fleurbaey, M., S. Kartha, S. Bolwig, Y.L. Chee, Y. Chen, E. Corbera, F. Lecocq, W. Lutz, M.S. Muylaert, R.B. Norgaard, C. Okereke, and A.D. Sagar. 2014. "Sustainable Development and Equity". Edenhofer, O.R. Pichs-Madruga, Y. Sokona, E. Farahani, S. Kadner, K. Seyboth, A. Adler, I. Baum, S. Brunner, P. Eickermeier, B. Kriemann, J. Savolainen, S. Schlomer, C. von Stechow, T. Zwickel and J.C. Minx eds. Climate Change 2014 - Mitigation of Climate Change: Contribution of Working Group III to the Fifth Assessment Report of the Intergovernmental Panel on Climate Change. Cambridge: Cambridge University Press.

Fossil Free MIT. 2014. “The Fossil Fuel Industry's Role in Hindering Climate Change Action: Lobbying and Disinformation against Science and Scientists". http://www.fossilfreemit.org/wp-content/uploads/2014/08/FossilFreeMITLobbying-Disinformation.pdf

Fourier, Joseph. 1827. "Mémoire sur les températures du globe terrestre et des espaces planétaires". Mémoires de l'Académie Royal des Sciences, Vol.7, pp.569604.

Frynas, Jedrzej Georg. 2000. Oil in Nigeria: Conflict and Litigation between Oil Companies and Village Communities. Hamburg: Lit Verlag Münster.

Gardiner, Stephen M. 2004. "Ethics and Global Climate Change". Ethics, Vol.114, pp.555-600.

--. 2011. A Perfect Moral Storm: The Ethical Tragedy of Climate Change. Oxford: Oxford University Press.

Garvey, James. 2008. The Ethics of Climate Change: Right and Wrong in a Warming World. London: Continuum International Publishing Group.

Government of Kenya. 2013. National Climate Change Action 2013-2017. Nairobi: Government of Kenya. http://cdkn.org/wp-content/uploads/2013/03/KenyaNational-Climate-Change-Action-Plan.pdf

Gyekye, Kwame. 2013. Philosophy, Culture and Vision - African Perspectives: Selected Essays. Accra: Sub-Saharan Publishers.

Hellsten, Sirkku, Frederick Ochieng-Odhiambo and Martin Schönfeld. 2013. "Climate Ethics: The End of Development or a New Paradigm through African Sagacity?" Schönfeld, Martin ed. Global Ethics on Climate Change: The Planetary Crisis and Philosophical Alternatives. London: Routledge, pp.89105.

Horner, Christopher C. 2007. The Politically Incorrect Guide ${ }^{\mathrm{TM}}$ to Global Warming and Environmentalism. Washington, DC: Regnery Publishing, Inc.

Humphreys, Stephen. 2009. "Introduction: Human Rights and Climate Change". Humphreys, Stephen ed. Human Rights and Climate Change. Cambridge: Cambridge University Press, pp.1-10.

Hutchful, Eboe. 1985. "Oil Companies and Environmental Pollution in Nigeria". Ake, Claude ed. 1985. Political Economy of Nigeria. London: Longman, pp.113140 . 
IPCC (Intergovernmental Panel on Climate Change). 2013. "Summary for Policymakers". Stocker, T.F., D. Qin, G.-K. Plattner, M. Tignor, S.K. Allen, J. Boschung, A. Nauels, Y. Xia, V. Bex and P. M. Midgley eds. Climate Change 2013 - The Physical Science Basis: Contribution of the Working Group I to the Fifth Assessment Report of the Intergovernmental Panel on Climate Change. Cambridge: Cambridge University Press.

--. 2014a. "Summary for Policy Makers”. Field, C.B., V.R. Barros, D.J. Dokken, K.J. Mach, M.D. Mastrandrea, T.E. Bilir, M. Chatteriee, K.L. Ebi, Y.O. Estrada, R.C. Genova, B. Girma, E.S. Kissel, A.N. Levy, S. MacCracken, P.R. Mastrandrea and L.L. Whits eds. Climate Change 2014: Impacts, Adaptation, and Vulnerability. Part A: Global and Sectoral Aspects. Contribution of Working Group II to the Fifth Assessment Report of the Intergovernmental Panel on Climate Change. Cambridge: Cambridge University Press, pp.1-32. --. 2014b. "Summary for Policy Makers". Edenhofer, O., R. Pich-Madruga, Y. Sokona, E. Farahani, S. Kadner, K. Seyboth, A. Adler, I. Baum, S. Brunner, P. Eickemeiler, B. Kriemann, J. Sayolainen, S. Schlomer, C. von Stechow, T. Zwickel and J.C. Minx eds. Climate Change 2014: Mitigation of Climate Change. Contribution of Working Group III to the Fifth Assessment Report of the Intergovernmental Panel on Climate Change. Cambridge: Cambridge University Press.

Irwin, Ruth. 2010. "Introduction". Irwin, Ruth ed. Climate Change and Philosophy: Transformational Possibilities. London: Continuum International Publishing Group, pp.1-17.

Irwin, William and Brian Williams. 2010. "An Ethical Defense of Global-Warming Skepticism”. Reason Papers, Vol.32, pp.7-27.

Ite, Aniefiok E. and Udo J. Ibok. 2013. "Gas Flaring and Venting Associated with Petroleum Exploration in the Nigeria's Niger Delta". American Journal of Environmental Protection, Vol.1 No.4, pp.70-77.

Jacques, P.J., R.E. Dunlap and M. Freeman. 2008. "The Organisation of Denial: Conservative think tanks and Environmental Scepticism”. Environmental Politics, Vol.17 No.3, pp.349-385.

Jamieson, Dale. 2001. "Climate Change and Global Environmental Justice". Edwards, P. and C. Miller eds. Changing the Atmosphere: Expert Knowledge and Global Environmental Governance. Cambridge, Mass.: MIT Press, pp.287307.

--. 2003. "Ethics, Public Policy, and Global Warming". Light, Andrew and Holmes Rolston III eds. Environmental Ethics: An Anthology. Oxford: Blackwell Publishers, pp.371-379.

Keith, David W. 2000. "Geoengineering the Climate: History and Prospect". Annual Review of Energy and the Environment, Vol.25, pp.245-284.

Kelbessa, Workineh. 2009. "Climate Change Impacts and Planning in Africa”. Gow, Kathryn ed. Meltdown: Climate Change, Natural Disasters and Other Catastrophes-Fears and Concerns for the Future. New York: Nova Science Publishers, pp.247-266.

--. 2011. Indigenous and Modern Environmental Ethics: A Study of the Indigenous Oromo Environmental Ethic and Modern Issues of Environment and Development. Ethiopian Philosophical Studies I. Washington, D.C.: The Council for Research in Values and Philosophy.

--. 2014. "Can African Environmental Ethics Contribute to Environmental Policy in Africa?" Environmental Ethics, Vol.36 No.1, pp.31-61. 
Knight, Carl. 2014. "Moderate Emissions Grandfathering”. Environmental Values, Vol.23, pp.571-592.

Kolstad, C., K. Urma, J. Broome, A. Bruvoll, M. Carino Olvera, D. Fullerton, C. Gollier, W.M. Hanemann, R. Hassan, F. Jotzo, M.R. Khan, L. Meyer and L. Mundaca. 2014. "Social, Economic and Ethical Concepts and Methods". Edenhofer, O.R. Pichs-Madruga, Y. Sokona, E. Farahani, S. Kadner, K. Seyboth, A. Adler, I. Baum, S. Brunner, P. Eickermeier, B. Kriemann, J. Savolainen, S. Schlomer, C. von Stechow, T. Zwickel and J.C. Minx eds. Climate Change 2014: Mitigation of Climate Change. Contribution of Working Group III to the Fifth Assessment Report of the Intergovernmental Panel on Climate Change. Cambridge: Cambridge University Press.

Layzer, Judith A. 2007. "Deep Freeze: How Business has Shaped the Global Warming Debate in Congress". Kraft, M.E. and S. Kamieniecki eds. Business and Environmental Policy. Cambridge, MA.: MIT Press, pp.93-125.

Light, Andrew. 2011. "Climate Ethics for Climate Action". Schmidtz, David and Elizabeth Willot eds. Environmental Ethics: What Really Matters? What Really Works? 2 ${ }^{\text {nd }}$ Ed. Oxford: Oxford University Press, pp.557-566.

Light, Andrew et al. 2012. "Doha Climate Summit Ends with the Long March to 2015: Near-Term Progress Now Depends on Fast Action in Other Forums". Centre for American Progress. http://www.americanprogress.org/wpcontent/uploads/2012/12/DohaClimate-1.pdf

Light, Andrew and Gwynne Taraska. 2014. "Climate Change, Adaptation, and Climate-Ready Development Assistance”. Environmental Values, Vol. 23, pp.129-147.

Lomborg, Bjørn. 2001. The Skeptical Environmentalist: Measuring the Real State of the World. Cambridge: Cambridge University Press.

Martin-Schramm, James B. 2010. Climate Justice: Ethics, Energy, and Public Policy. Minneapolis: Fortress Press.

Munyaka, Mluleki and Mokgethi Motlhabi. 2009. "Ubuntu and its Socio-moral Significance". Murove, Munyradzi Felix ed. African Ethics: An Anthology of Comparative and Applied Ethics. Scottsville: University of KwaZulu-Natal Press, pp.63-84.

Murove, Munyaradzi Felix. 2004. "An African Commitment to Ecological Conservation: The Shona Concepts of Ukama and Ubuntu". Mankind Quarterly, Vol.XLV, pp.195-215.

NCCR (National Climate Change Response). 2004. "National Climate Change Response: White Paper". Department of Water and Environmental Affairs, South Africa. http://www.sanbi.org/sites/default/files/documents/documents/nationalclimate-changeresponse-white-paper.pdf

Neumayer, Eric. 2000. "In Defence of Historical Accountability for Greenhouse Gas Emissions". Ecological Economics, Vol.33 No.2, pp.185-192.

Niang,I., O.C. Ruppel, M.A. Abdrabo, A. Essel, c. Lennard, J. Padgham and P. Urquhart. 2014. “Africa”. Barros, V. R., C.B. Field, D.J. Dokken, M.D. Mastrandrea, K.J. Mach, T.E. Bilir, M. Chatterjee, K.L. Ebi, Y.O. Estrada, R.C. Genova, B. Girma, E.S. Kissel, A.N. Levy, S. MacCracken, P.R. Mastrandrea and 1.L. White eds. Climate Change 2014: Impacts, Adaptation, and Vulnerability. Part B: Regional Aspects. Contribution of Working Group II to the Fifth Assessment Report of the Intergovernmental Panel on Climate change. Cambridge: Cambridge University Press, pp.1199-1265. 
OECD. 1975. The Polluter Pays Principle. Paris: OECD.

Olivier, J.G.J, Greet Janssens-Maenhout, Marilena Muntean, Jeroen A.H.W. Peters. 2015. Trends in Global CO2 Emissions: 2015 Report. The Hague: PBL Netherlands Environmental Assessment Agency; Ispra: European Commission, Joint Research Centre.

Oreskes, Naomi and Erik M. Conway. 2010. Merchants of Doubt: How a Handful of Scientists Obscured the Truth on Issues from Tobacco Smoke to Global Warming. New York: Bloomsbury.

Oulu, Martin. 2014. "Kenya's Consideration of Ethics and Justice Issues in Formulating Climate Change Policies". Brown, Donald and Prue Taylor eds. Ethics and Climate Change: A Study of National Commitments. Gland: IUCN, pp.87-94.

Perrot, Radhika. 2014. "South Africa's Consideration of Ethics and Justice Issues in Formulating Climate Change Policies". Brown, Donald and Prue Taylor eds.

Ethics and Climate Change: A Study of National Commitments. Gland: IUCN, pp.123-133.

Ramose, Mogobe B. 2002. African Philosophy through Ubuntu, Revised edition. Harare: Mond Books.

--. 2003. "Ubuntu Philosophy". Coetzee, P.H. and A.P. Roux eds. The African Philosophy Reader: A Text With Readings. $2^{\text {nd }}$ Ed. Cape Town: Oxford University Press of Southern Africa, pp.270-280.

--. 2013. "An African Perspective on the Strategic Significance of HIV/AIDS for Africa and Her Diaspora". Ramose, Mogabe B. ed. Hegel's Twilight: Liber Amicorum Discipulorumque Pro Heinz Kimmerle. Amsterdam: Rodopi, pp.372-390.

Rentmeester, Casey. 2014. "Do No Harm: A Cross-Disciplinary, Cross-Cultural Climate Ethics". De Ethica: A Journal of Philosophical, Theological and Applied Ethics, Vol.1 No.2, pp.5-22.

Rolston, Holmes III. 2012. A New Environmental Ethics: The Next Millennium for Life on Earth. New York: Routledge.

Shue, Henry. 1993. "Subsistence Emissions and Luxury Emissions". Law and Policy, Vol.15 No.1, pp.39-59.

--. 1999. "Global Environment and International Inequality”. International Affairs, Vol.75 No.3, pp.531-545.

Singer, Peter. 2002. One World: the Ethics of Globalization. $2^{\text {nd }}$ Ed. New Haven: Yale University Press.

Singer, S. Fred. 1997. Hot Talk: Cold Science. Oakland, Calif.: Independent Institute.

Sterba, J.P. 2009. "Our Basic Human Right is a Right to Liberty and it Leads to Equality”. Sterba, J.P. ed. Ethics: the Big Questions. $2^{\text {nd }}$ Ed. Chichester: Wiley-Blackwell, pp.285-295.

Tutu, Desmond. 1999. No Future Without Forgiveness. London: Rider and Random House.

Tyndall, John. 1861. "On the Absorption and Radiation of Heat by Gases and Vapours". Philosophical Magazine, Vol.22, pp.169-194, 273-285.

UNDP (United Nations Development Programme). 2011. Down to Earth: Territorial Approach to Climate Change - Low-Emission and Climate-Resilient Development Strategies at the Sub-National Level. 2011 Update, Down to Earth: Territorial Approach to Climate Change (TACC) Project of the United Nations Development Programme (UNDP), UNDP, New York, USA. 
UNFCCC (United Nations Framework Convention on Climate Change). 1992. http://unfccc.int/essential background/convention/items/6036.php

--. 2014a. "Kyoto Protocol”. http://unfccc.int/kyoto_protocol/items/3145.php

--. 2014b. "Status of the Doha Amendment". http://unfccc.int/kyoto protocol/doha amendment/items/7362.php

--. 2015. "Paris Agreement". http://unfccc.int/files/essential_background/convention/application/pdf/english _paris_agreement.pdf

van Rooy, J.A. 1997. "Scriptural Ethical Principles and Traditional African Ethics". In die Skriflig, Vol.31 Nos.1 \& 2, pp.93-106.

Williams, Charles J.R. and Dominic R. Kniveton. 2011. "Introduction”. Williams, Charles J.R. and Dominic R. Kniveton eds. African Climate and Climate Change: Physical, Social and Political Perspectives. London: Springer, pp.112.

Wiredu, Kwasi. 1994. "Philosophy, Humankind and the Environment". Odera Oruka, H. ed. Philosophy, Humanity and Ecology. Vol. I: Philosophy of Nature and Environmental Ethics. Nairobi: ACTS Press and AAS, pp.30-48. 